\title{
Sistem Informasi Palang Merah Indonesia (PMI) Dengan Menggunakan Visual Basic.Net
}

\author{
Sophan Sophian \\ Dosen STMIK Indonesia Padang \\ Ophan@stmikindonesia.ac.id
}

\begin{abstract}
ABSTRAK
Indonesian red cross an organization nonprofit having tasks and functions to make public services in socially, health and humanity. But the services in the health sector is blood donating service conducted by a unit blood donation pmi. In the implementation of these services unit blood donation still use a data processing system manually.A data processing system that manual are often have been several issues like processing, search and presentation of data requires a relatively long time and high risk of damage or lose some data for not arranged in orderly and the absence of data base blood donation. So, blood donation service performance by unit the blood donation still has not been effectively and efficiently. In the challenge of increased service performance donor unit of the blood, writer saw the need of attempts to the transformation of a data processing system manually
\end{abstract}

Keywords: System Information, Processing Data, Blood Donation

\section{PENDAHULUAN}

Saat ini teknologi diberbagai bidang telah mengalami perkembangan dan kemajuan yang begitu pesat terutama dibidang teknologi informasi. Perubahan dari proses manual menuju penerapan teknologi informasi berbasis komputerisasi telah meningkatkan efisiensi dan efektivitas pekerjaan manusia. Dengan segala kelebihannya, komputerisasi telah membantu pekerjaan manusia secara pribadi maupun pekerjaan dalam sebuah organisasi baik diorganisasi publik, oganisasi privat maupun organisasi semi publik. Komputerisasi ini berkaitan dengan peningkatan ketepatan, kecepatan dan keakuratan dalam pengolahan data untuk memperoleh informasi serta informasi selajutnya dimamfaatkan untuk dasar pengambilan keputusan.
Organisasi Palang Merah Indonesia (PMI) merupakan organisasi nonprofit atau semi publik yang memiliki peran aktif dan strategik dalam bidang sosial kemanusiaan. PMI dalam menjalankan akivitas kerja organisasinya berperan dalam hal menyelenggarakan pelayanan kepalangmerahan yang bermutu dan tepat waktu dengan cakupan kerja sebagai berikut :

1. Penyelenggaraan bantuan kemanusiaan dalam keadaan darurat.

2. Penyelenggaraan pelayanan sosial dan kesehatan masyarakat.

Organisasi Palang Merah Indonesia memiliki struktur Kepengurusan dari mulai tingkat pusat kemudian tingkat provinsi dan tingkat kabupaten diseluruh indonesia. Hal ini bertujuan untuk lebih menunjang penyelenggaraan tugas dan fungsi PMI bagi

192 Diterbitkan Oleh Program Studi Pendidikan Informatika STKIP PGRI Sumbar 
masyarakat dalam bidang sosial, kesehatan dan kemanusiaan.

Fokus Kerja Utama PMI terletak dibagian Unit Donor Darah (UDD). Unit Donor Darah (UDD) adalah salah satu Bidang didalam Organisasi PMI yang memiliki tugas dan fungsi dalam hal penyelengaraan pelayanan Kesehatan dibidang donor darah. Penyelenggaraan Pelayanan donor darah dibagi kedalam beberapa fokus kegiatan yaitu :

1. Pendataan Pendonor Darah

2. Pendataan Penerimaan Darah

3. Pendataan Permintaan Darah

4. Pendataan Stok/Ketersediaan dan Jenis Darah

Dari lima Fokus Kerja Penyelenggaraan pelayanan donor darah tersebut selanjtnya diproses menjadi sekumpulan Data Utama Unit Donor Darah (UDD) yang kemudian ditampilkan sebagai sebuah laporan. Laporan Unit Donor Darah (UDD) terdiri dari :

1. Laporan Penerimaan Donor Darah

2. Laporan Permintaan Donor Darah

3. Laporan Persediaan Darah

Selama ini, Proses penyelenggaraan Pelayanan donor darah di Unit Donor Darah (UDD) PMI masih menerapkan proses manual. Dari informasi yang didapatkan dalam observasi awal, diketahui bahwa proses manual dalam penyelenggaraan pelayanan donor darah di Unit Donor Darah (UDD) PMI memiliki masalah - masalah sebagai berikut :

1. Pernah terjadi kesalahan yang mengakibatkan data menjadi rancu dan tidak akurat dalam hal pencatatan ketersediaan (stock) dan jenis darah.
2. Proses pendataan secara manual tidak tersusun dengan rapi dan tertib.

3. Karena Proses pengolahan data utama UDD masih secara manual maka untuk mengelola data utama menjadi sebuah laporan harian, mingguan, bulanan dan tahunan memerlukan waktu yang lama. Akibatnya informasi menjadi telat diperoleh oleh pimpinan untuk mengambil sebuah keputusan.

4. Proses penyimpanan data yang masih manual sangat rentan terhadap kerusakan dan kehilangan.

Dari permasalahan diatas dapat kita ketahui bahwa proses manual jelas tidak efektif dan efisien dalam penyelenggaran pelayanan donor darah di Unit Donor Darah (UDD) PMI sehingga Unit Donor Darah (UDD) PMI tidak belum memamfaatkan perkembangan teknologi informasi khususnya dalam suatu proses pendataan maupun dalam hal penyajian data, yaitu pengolahan data penyelenggaraan pelayanan donor darah dan penyajian data utama menjadi sebuah Laporan.

Untuk itu tugas akhir ini saya rancang agar dapat memudahkan pengolahan data maupun penyajian data menjadi sebuah informasi yang berguna dalam pengambilan keputusan secara lebih tepat dan akurat sebagai penunjang kinerja organisasi PMI khususnya di Unit Donor Darah (UDD), yaitu dengan mengkomputerisasikan proses pendataan penyelenggaraan pelayanan donor darah dan penyajian data utama menjadi sebuah informasi maupun Laporan melalui pengolahan informasi database.

Aplikasi ini memberikan Informasi Pendataan Pelayanan Donor Darah dan Penyajian Laporan bagi Unit Donor Darah (UDD) PMI dalam implementasinya 
menggunakan bahasa pemrograman Visual Basic.Net sebagai aplikasi perancangannya.

\section{ANALISIS DAN PERANCANGAN \\ 1. Pengertian Analisis Sistem}

Menurut Hanif Al Fatta (2007:44) Analisis Sistem adalah teknik pemecahan masalah yang menguraikan bagian-bagian komponen dengan mempelajari seberapa bagus bagian-bagian komponen tersebut bekerja dan berinteraksi untuk mencapai tujuan mereka.

Menurut Jogiyanto HM, MBA, Akt.,Ph.d. (2005:129) bahwa :Analisis sistem adalah penguraian dari suatu sistem informasi yang utuh kedalam bagian-bagian komponennya dengan maksud untuk mengidentifikasikan dan mengevaluasi permasalahan-permasalahan, kesempatankesempatan, hambatan-hambatan yang terjadi dan kebutuhan-kebutuhan yang diharapkan sehingga dapat diusulkan perbaikan-perbaikannya.

Maka, dapat disimpulkan bahwa Analisis Sistem merupakan proses pemahaman dan penentuan rincian yang harus diselesaikan oleh sistem informasi

Tahap analisis sistem dilakukan setelah tahap perencanaan sistem (systems planning) dan sebelum tahap desain sistem (system design). Tahap analisis merupakan tahap yang kritis dan sangat penting, karena kesalahan dalam tahap ini akan menyebabkan juga kesalahan ditahap selanjutnya.

\section{Langkah-langkah Sistem}

Didalam analisis sistem terdapat langkah-langkah dasar yang harus dilakukan oleh analis sistem, antara lain : a. Mengidentifikasi Masalah (identify)
Mengidentifikasi masalah merupakan langkah pertama yang dilakukan dalam tahap analisis sistem. Masalah dapat didefenisikan sebagai suatu pernyataan yang diinginkan untuk dipecahkan.

b. Memahami kerja dari suatu sistem yang ada (understand)

Langkah ini dapat dilakukan dengan mempelajari secara terinci bagaimana sistem yang ada beroperasi. Untuk mempelajari dari sistem ini diperlukan data yang dapat diperoleh dengan cara melakukan penelitian.

c. Menganalisis sistem (analyze)

Langkah ini untuk menganalisis masalah yang terjadi untuk menemukan penyebab dari masalah yang timbul berdasarkan data yang telah diperoleh dari hasil penelitian yang telah dilakukan.

d. Membuat laporan hasil analisis (report)

Setelah proses analisis selesai dilakukan, selanjutnya analis sistem membuat laporan hasil analisis.

\section{Pengertian Desain Sistem}

Menurut John Burch \& Gary Grudnitski dalam Jogiyanto (2005:196) Desain sistem dapat didefenisikan sebagai penggambaran, perencanaan, dan pembuatan sketsa atau pengaturan dari beberapa elemen yang terpisah ke dalam satu kesatuan yang utuh dan berfungsi.

Menurut Hanif Al Fatta (2007:44) Desain Sistem adalah sebuah teknik pemecahan masalah yang saling melengkapi (dengan analisis sistem) yang merangkai kembali bagian-bagian komponen menjadi sistem yang lengkap harapannya, sebuah sistem yang diperbaiki.

Maka, dapat disimpulkan bahwa Desain Sistem adalah proses pengembangan 
spesifikasi sistem baru berdasarkan rekomendasi hasil analisis sistem.

\section{Palang Merah Indonesia (PMI)}

\section{Sejarah Palang Merah Indonesia}

Palang Merah Indonesia adalah sebuah organisasi perhimpunan nasional di Indonesia yang bergerak dalam bidang sosial kemanusiaan.PMI selalu berpegang teguh pada tujuh prinsip dasar Gerakan Internasional Palang Merah dan Bulan sabit merah yaitu kemanusiaan, kesamaan, kesukarelaan, kemandirian, kesatuan, kenetralan, dan kesemestaan.

Perjuangan untuk mendirikan Palang Merah Indonesia sendiri diawali sekitar tahun 1932. Kegiatan tersebut dipelopori oleh Dr. RCL Senduk dan Dr Bahder Djohan. Rencana tersebut mendapat dukungan luas terutama dari kalangan terpelajar Indonesia. Mereka berusaha keras membawa rancangan tersebut ke dalam sidang Konferensi Nerkai pada tahun 1940 walaupun akhirnya ditolak mentah-mentah. Terpaksa rancangan itu disimpan untuk menunggu kesempatan yang tepat. Seperti tak kenal menyerah, saat pendudukan Jepang, mereka kembali mencoba untuk membentuk Badan Palang Merah Nasional, namun sekali lagi upaya itu mendapat halangan dari Pemerintah Tentara Jepang sehingga untuk kedua kalinya rancangan itu harus kembali disimpan.

Tujuh belas hari setelah proklamasi kemerdekaan 17 Agustus 1945, yaitu pada tanggal 3 September 1945, Presiden Soekarno mengeluarkan perintah untuk membentuk suatu badan Palang Merah Nasional. Atas perintah Presiden, maka Dr. Buntaran yang saat itu menjabat sebagai Menteri Kesehatan Republik Indonesia Kabinet I, pada tanggal 5 September 1945 membentuk Panitia 5 yang terdiri dari: dr R.
Mochtar (Ketua), dr. Bahder Djohan (Penulis), dan dr Djuhana; dr Marzuki; dr. Sitanala (anggota).

Akhirnya Perhimpunan Palang Merah Indonesia berhasil dibentuk pada 17 September 1945 dan merintis kegiatannya melalui bantuan korban perang revolusi kemerdekaan Republik Indonesia dan pengembalian tawanan perang sekutu maupun Jepang. Oleh karena kinerja tersebut, PMI mendapat pengakuan secara Internasional pada tahun 1950 dengan menjadi anggota Palang Merah Internasional dan Palang Merah Indonesia disahkan secara nasional yaitu melalui Keputusan Presiden Republik Indonesia Serikat No. 25 Tahun 1950 yang dikeluarkan tanggal 16 Januari 1950. Pada 29 November 1963 pemerintah Republik Indonesia melalui Keputusan Presiden No. 246 Tahun 1963 melengkapi Keppres No. 25 Tahun 1950. Melalui Keppres ini pemerintah Republik Indonesia mengesahkan : Tugas Pokok dan Kegiatan - Kegiatan Palang Merah Indonesia yang berazaskan Perikemanusiaan dan atas dasar sukarela dengan tidak membeda bedakan bangsa, golongan dan faham politik.

Selanjutnya melalui PP No. 18 Tahun 1980, pemerintah memberikan tugas khusus kepada Palang Merah Indonesia untuk menyelenggarakan Upaya Kesehatan Transfusi Darah (UKTD). Tugas ini dilaksanakan secara tersendiri, otonom dengan, bimbingan, pengawasan dan pembinaan, baik oleh jajaran Kepengurusan PMI maupun jajaran Departemen Kesehatan. Kegiatan ini mencakup :
a. Pemilihan (seleksi) penyumbang darah
b. Penyadapan darah
c. Pengamanan darah 


\section{d. Penyimpanan darah \\ e. Penyampaian darah}

Pengadaan darah dilakukan atas dasar "sukarela" tanpa maksud mencari keuntungan maupun menjadikan darah objek jual beli.Hasil kegiatan UKTD PMI adalah darah yang sehat, aman dan tersedia tepat waktu. Disamping itu darah dapat diolah menjadi komponen - komponen darah yang dapat diberikan kepada pasien dengan tepat sesuai kebutuhan.

\section{Pelayanan Donor DarahOleh PMI}

Pemerintah menugaskan hanya kepada PMI untuk menyelenggarakan kegiatan transfusi darah sesuai PP No. 18 tahun 1980 diperkuat dengan :PeraturanMenteriKesehatan RINo : 478/ Men Kes/1990 dan Peraturan Pemerintah Republik Indonesia Nomor 7 tahun 2011 yang substansinya sebagai berikut :

1. Penyelenggaraan Upaya Kesehatan
Transfusi Darah dilaksanakan oleh
UTD PMI

2. Kegiatan UTD:

Rekruitment donor, Penyadapan Darah, Pengamanan Darah, Pengolahanddarath, Penyimpanan Darah dan Distribusi Darah

3. Penyumbang Darah Sukarela dan Tidak Diperjual Belikan

4. Pengolahan darah disesuaikan dengan standard

5. Penyimpanan Darah harus sesuai dengan teknis Penyimpanan yang baik (suhu, tempat, lama penyimpanan dll)

6. Penyelenggaraan dibawah pengawasan Dokter

7. Perizinan oleh Depkes / melalui Dinkes setempat

8. 8. Pengiriman dan penerimaan darah dari dan ke Indoneia hanya untuk kepentingan Ilmiah atau Kerja Sama dg Palang Mearah Internasional lain.

9. Subsisdi dapat diberikan oleh Pemerintah

10. BPPD ditetapkan oleh Pemerintah atas usulan UTD PMI melalui

11. Dinas kesehatan dengan surat keputusan gubernur.

12. Kepada Penyumbang Darah dapat diberikan Penghargaan :

13. Piagam, peniti dan medali.

\section{Unit Donor Darah PMI}

Tugas dan fungsi Unit Donor Darah PMI adalah mencakup masalah pengadaan, pengolahan, penyimpanan dan pendistribusian darah beserta komponenkomponennya guna melayani kebutuhan penderita secara luas, merata dan aman dengan memperhatikan syarat-syarat kesehatan.

Tujuan Umum Unit Donor Darah PMI adalah terpenuhinya kebutuhan darah dan komponen-komponennya bagi penderita yang memerlukan secara mudah, cepat dan aman (Safety Blood).

Tujuan Khusus Unit Donor Darah PMI

a. Tersedianya serta kesiapan para donor darah sukarela dalam jumlah yang cukup.

b. Terselenggaranya pelayanan donor darah yang memadai.

c. Terselenggaranya pemeriksaan laboratorium yang terjamin mutu dan kualitas.

d. Terselenggaranya penyaluran darah secara cepat, tepat dan aman.

e. Terselenggaranya kegiatan penelitian dan pengembangan serta upaya rujukan.

Struktur dan Pembagian Kerja di Organisasi PMI 


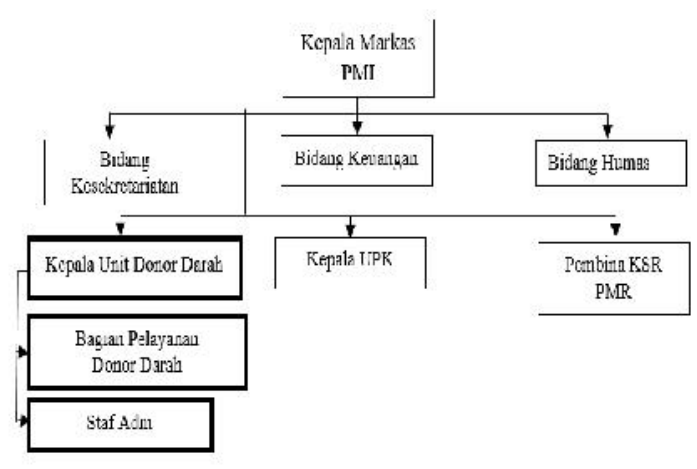

Gambar Struktur Organisasi PMI

\section{Prosedur Pelayanan Donor Darah}

Donor darah merupakan Individu atau orang yang menyumbangkan darahnya, dengan tujuan untuk membantu yang lain khususnya yang pada kondisi memerlukan suplai darah dari luar, karena sampai saat ini darah belum bisa di sentesa sehingga ketika di perlukan harus di ambil seorang/individu. Golongan darah manusia terdiri dari 4 Golongan darah yaitu : A, B, $\mathrm{AB}, \mathrm{O}$. Tempat untuk mendonorkan darah sukarela adalah Unit Donor Darah (UUD) dikelola oleh Palang Merah Indonesia (PMI) yang salah satu tugasnya sebagai membantu dalam pelayanan masyarakat di bidang Kesehatan.

\section{Syarat-syarat Teknis Menjadi Donor Darah}

Umur 17-60 tahun (Pada usia 17 tahun diperbolehkan menjadi donor bila mendapat ijin terulis dari orang tua. Sampai usia tahun donor masih dapat menyumbangkan darahnya dengan jarak penyumbang 3 bulan atas pertimbangan dokter ).

1. Berat badan minimum $45 \mathrm{~kg}$

2. Temperatur tubuh : $36,3-37,5 \mathrm{Oc}$ (oral)

3. Tekanan darah baik, yaitu:
a. Sistole $=110-160 \mathrm{~mm} \mathrm{Hg}$
b. Diastole $=70-100 \mathrm{~mm} \mathrm{Hg}$

4. Denyut nadi: Teratur $50-100$ kali/ menit

5. Hemoglobin
a. Wanita minimal $=12 \mathrm{gr} \%$
b. Pria Minimal $=12,5 \mathrm{gr} \%$

6. Jumlah penyumbangan pertahun paling banyak 5 kali, dengan jarak penyumbanagan sekurang-kurangnya 3 bulan. Keadaan ini harus sesuai dengan keadaan umum donor.

\section{Manfaat Donor Darah}

a. Dapat memeriksakan kesehatan secara berkala 3 bulan sekali seperti tensi, Lab Uji Saring (HIV, Hepatitis B, C, Sifilis dan Malaria).

b. Mendapatkan piagam penghargaan sesuai dengan jumlah penyumbang darahnya antara lain 10, 25, 50, 75, 100 kali.

c. Donor darah 100 kali mendapatkan penghargaan Satya Lencana Kebaktian Sosial dari Pemerintah.

d. Merupakan bagian dari ibadah.

Untuk terciptanya disiplin serta meminimalisasi terjadinya hal-hal yang tidak diinginkan, maka terdapat juga sistem dan mekanisme dalam pelaksanaan donor darah yaitu:

1) Donor menyerahkan kartu donornya kepada petugas transfusi bila sudah pernah donor, dan yang baru nantinya setelah menyumbangkan darahnya akan di buatkan kartu donor

2) Donor ditimbang berat badannya

3) Donor dites golongan darahnya dan kadar Haemoglobin (HB) 
4) Setelah memenuhi untuk menjadi donor sesuai persyaratan di atas seperti HB normal, berat badan cukup, maka donor dipersilahkan tidur untuk diperiksa kesehatannya oleh dokter transfuse

5) Setelah memenuhi syarat (sehat menurut dokter) barulah petugas transfusi darah (AID/PTID) siap untuk menyadap (mengambil) darahnya berdasarkan berat badan (250cc $500 \mathrm{cc}$ )

6) Setelah diambil daranya donor dipersilahkan ke kantin donor untuk menikmati hidangan ringan berupa kopi/susu, telor dan vitamin

7) Donor kembali ke bagian administrasi untuk mengambil kartu donornya yang telah diisi tanggal penyumbang dan registrasi oleh petugas

8) Selesai (pulang), dan bisa kembali meyumbangkan darahnya setelah 75 hari (2,5 bulan)

Yang dimaksud dengan pengolahan darah adalah tahapan kegiatan untuk mendapatkan darah sampai dengan kondisi siap pakai, yang menckup antara lain :

a) Rekruitmen donor

b) Pengambilan darah donor

c) Pemeriksaan uji saring

d) Pemisahan darah menjadi komponen darah

e) Pemeriksaan golongan darah

f) Pemeriksaan kecocokan darah donor dengan pasien

g) Penyimpanan darah di suhu tertentu

h) Dan lain-lain

\section{DESAIN SISTEM \\ Desain Global}

Perancangan global atau desain konseptual (conceptual design) atau disebut juga dengan desain logika (logical design), yaitu perancangan prosedur sistematika, logika, atau algoritma sistem secara konseptual yang berfungsi untuk membenahi sistem yang sedang berjalan. Dalam perancangan global ini, akan diuraikan bagan arsitektur sistem yang diusulkan berupa, HIPO (Hierarchy Plus Input Process Output), DFD (Data Flow Diagram), ERD (Entity Relationship Diagram).

\section{Hierarchy Plus Input Process Output( HIPO )}

HIPO yang dirancang untuk Sistem Informasi Palang Merah Indonesia dapat dilihat pada Gambar berikut ini:

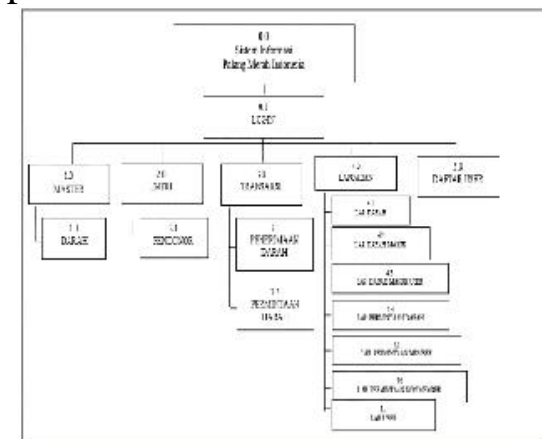

\section{Gambar HIPOSistem Informasi Palang Merah Indonesia}

\section{A. Desain Terinci}

Perancangan secara terinci yang disebut juga dengan desain teknis sistem secara fisik (psysical system design) atau disebut juga dengan desain internal (internal design), yaitu perancangan bentuk fisik atau bagan arsitektur sistem yang diusulkan, pengolahan data ini diharapkan dapat mempermudah dalam hal penyajian, pelayanan dan pembuatan berbagai laporan data yang dibutuhkan. Berdasarkan hal 


\section{Jurnal Edik Informatika}

ISSN : 2407-0491

Penelitian Bidang Komputer Sains dan Pendidikan Informatika V2.i2(192-202)

tersebut di atas, akan diuraikan lebih detail rancangan sistem yang diusulkan.

\section{Struktur Menu Utama}

Desain menu utama untuk admin, program yang dirancang untuk Sistem Informasi Palang Merah Indonesia dapat dilihat pada Gambar berikut :

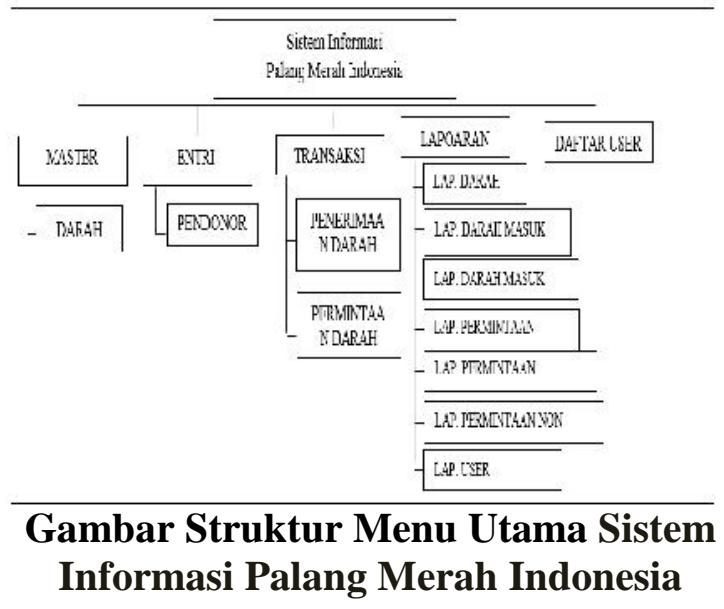

\section{Perancangan Ouput}

Designoutput adalah rancangan bentuk informasi yang akan dihasilkan pada sistem, designoutput ini merupakan pengembangan dari bentuk output pada aplikasi sedang dipakai. Adapun bentuk output yang dirancang dalam aplikasiSistem Informasi Palang Merah Indonesia.

\section{Tabel Laporan Darah}

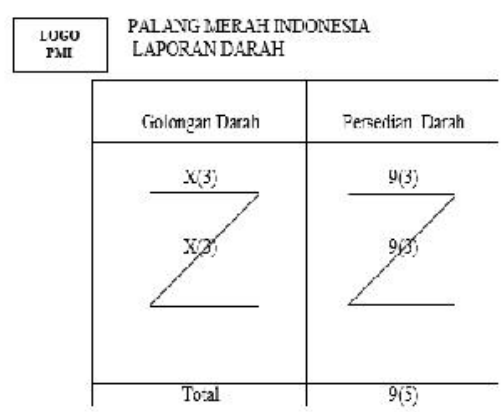

Tabel Laporan Darah Masuk

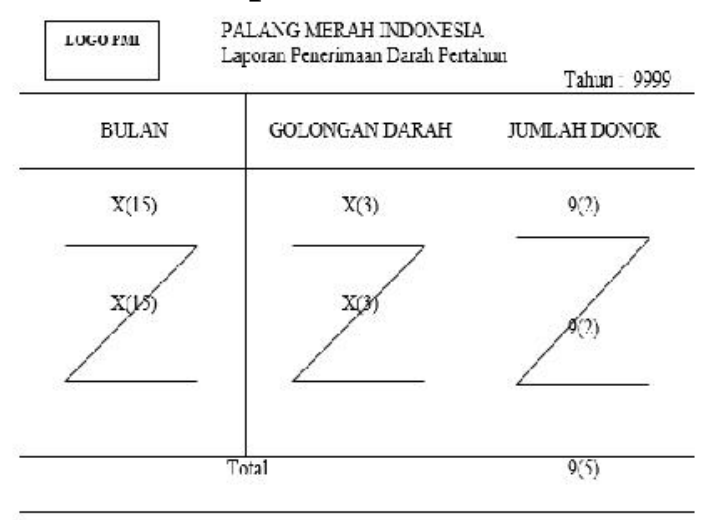

\section{Tabel Laporan Darah Masuk User}

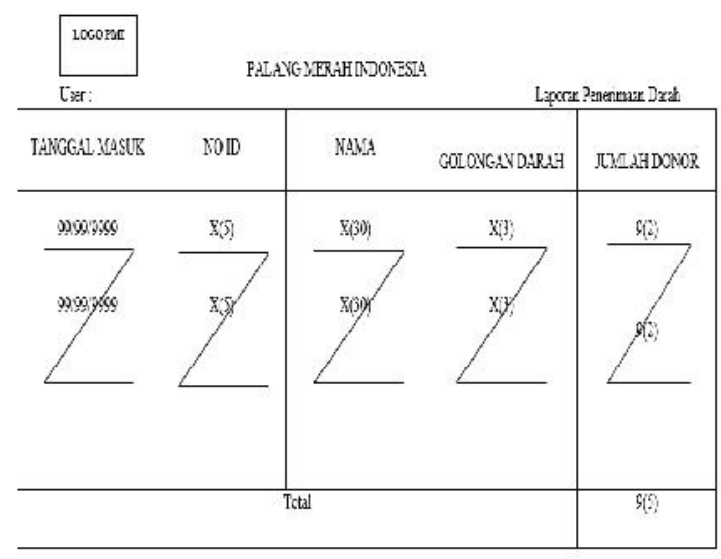

Tabel Laporan Darah Keluar

LOGO PMI PALANG MERAH INDONESIA.

Laporan Fermintaan Darah Pertahun

\begin{tabular}{|c|c|c|}
\hline BULAN & GOLONGAN DARAH & JJMLAH DONOR \\
\hline $\mathrm{X}(15)$ & $\mathrm{X}(3)$ & $9(2)$ \\
\hline \multicolumn{2}{|c|}{ Total } & $9(5)$ \\
\hline
\end{tabular}




\section{Jurnal Edik Informatika}

ISSN : 2407-0491

E-ISSN : 2541-3716

Penelitian Bidang Komputer Sains dan Pendidikan Informatika V2.i2(192-202)

Tabel Laporan Permintaan Member

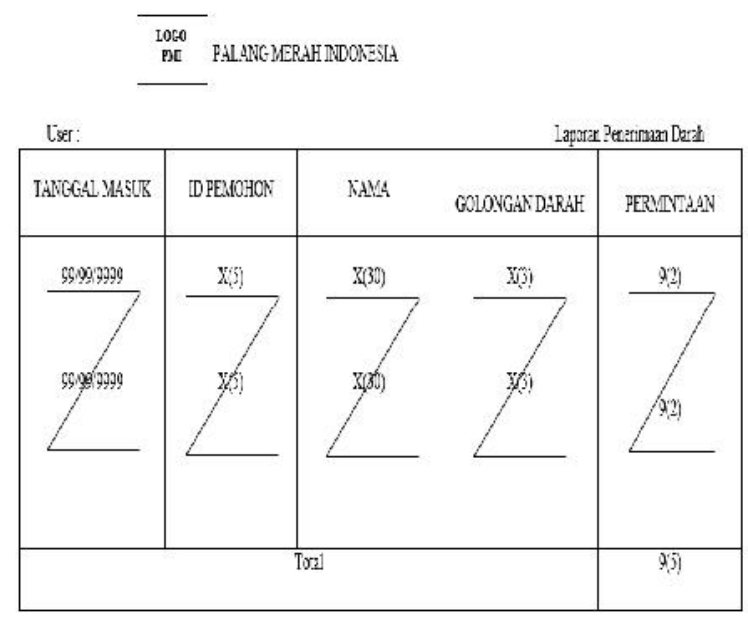

Tabel Laporan Permintaan non Member

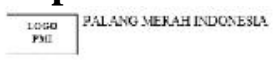

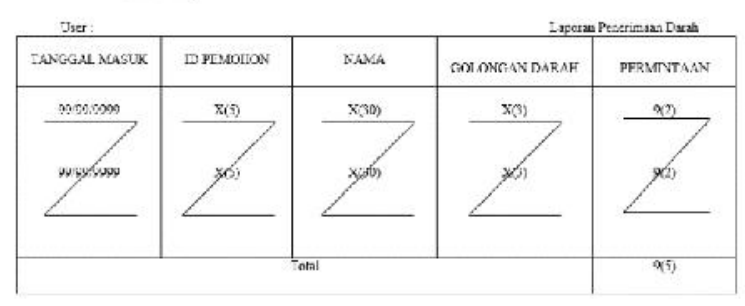

Tabel Laporan User

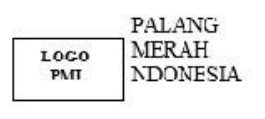

\begin{tabular}{|l|l|l|}
\hline NAMA USER & WAKTL MASUK & WAKTU KELUAR \\
\hline $\mathrm{X}(25)$ & $\frac{99 / 99 / 9959}{29 / 59 / 9999}$ \\
\hline $\mathrm{X}(25)$ & & \\
\hline
\end{tabular}

\section{Master Darah}

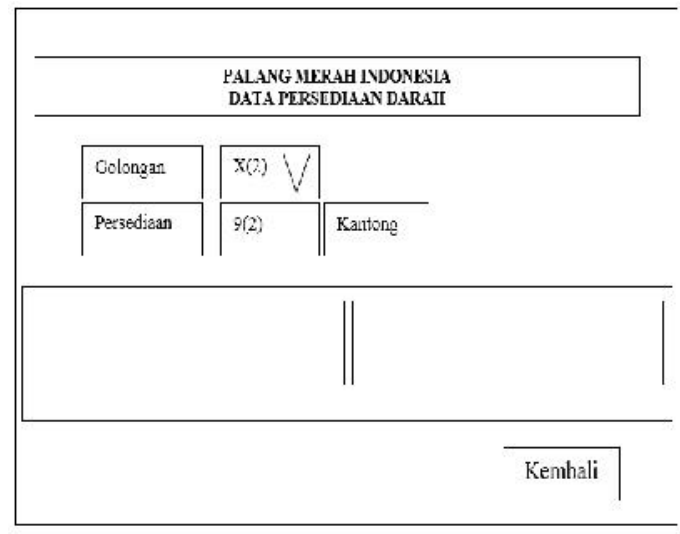

Gambar Master darah

2. Entri Data Pendonor

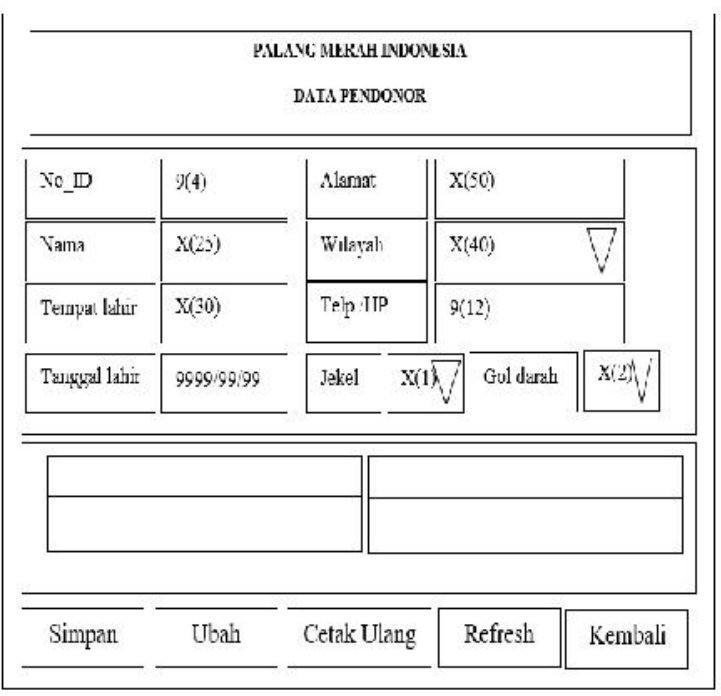

Gambar Entry data pendonor

\section{Perancangan Input}

Rancangan input merupakan masukan dari suatu sistem yang akan diproses yang mana bentuk rancangannya sebagai berikut : 


\section{Jurnal Edik Informatika}

ISSN : 2407-0491

Penelitian Bidang Komputer Sains dan Pendidikan Informatika

V2.i2(192-202)

3. Proses Data Penerimaan Darah

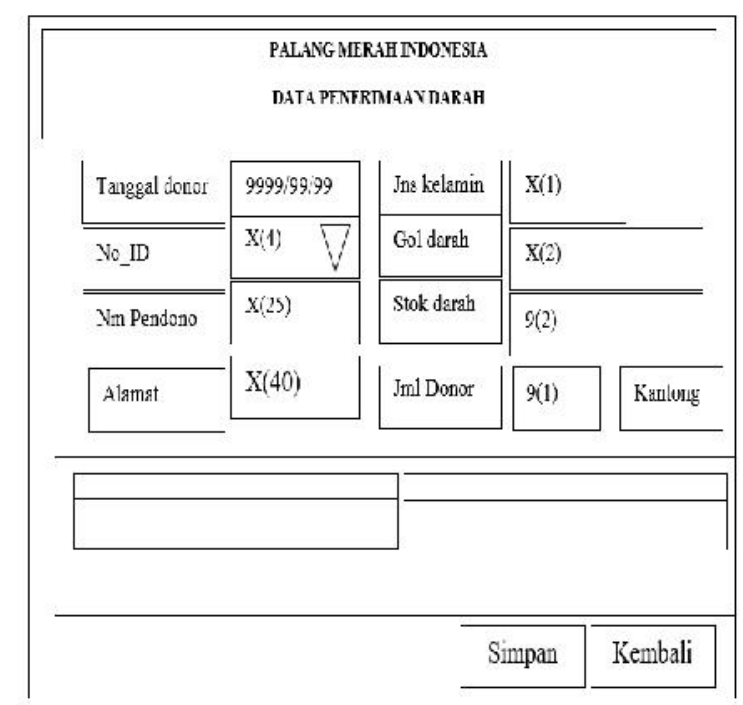

Gambar Proses Data Penerimaan Darah

4. Proses Data Permintaan Darah non Member

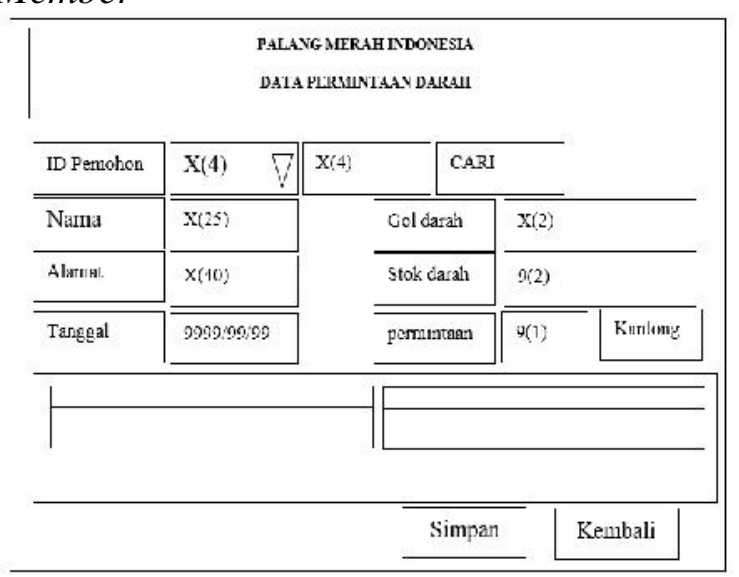

Gambar Proses data permintaan darah Member
5. Proses Data Permintaan Darah Member

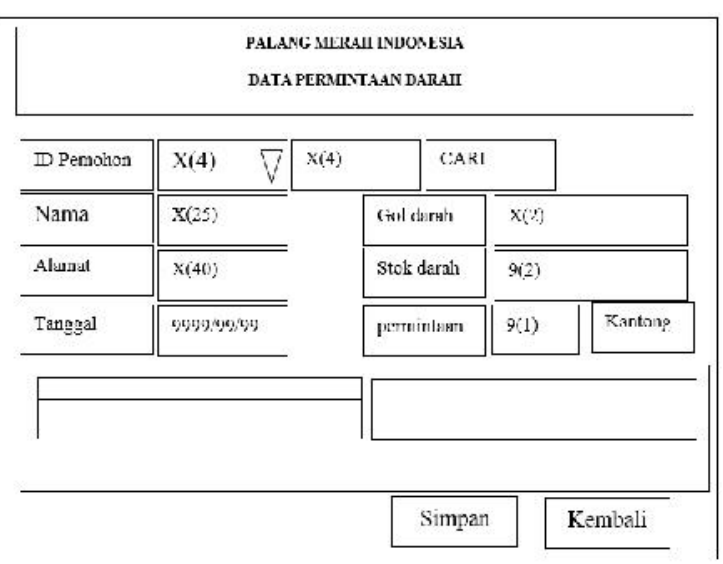

Gambar Proses data permintaan darah Member

\section{KESIMPULAN}

Berdasarkan pembahasan yang dilakukan pada bab-bab sebelumnya maka dapat diuraikan kesimpulan dan saran untuk meningkatkan pelayanan donor darah di Palang Merah Indonesia secara maksimal pada Sistem Informasi Palang Merah Indonesia dengan menggunakan bahasa pemrograman Visual Basic.Net. Adapun kesimpulan dari pembahasan yaitu :

1. Dengan adanya Aplikasi sistem informasi maka pendataan donor darah sudah semakin rapi dan tertib dan data yang sudah dientrikan oleh Petugas transfusi akan mudah untuk diketahui karena data telah tersimpan di database dan dapat dilihat pada form aplikasi Sistem Informasi Palang Merah Indonesia.

2. Dengan adanya database pada program aplikasi sistem informasi pengolah data Unit Donor Darah Palang Merah Indonesia maka keamanan data lebih terjamin dan proses pengambilan data untuk 
pembuatan laporan akan lebih cepat, tepat dan akurat. Laporan bisa diminta kapan saja sesuai dengan kebutuhan. karena data yang dientrikan oleh Petugas transfusi sudah masuk ke dalam aplikasi Sistem Informasi.

\section{DAFTAR PUSTAKA}

Abdul Kadir. 2014.

PengenalanSistemInformasiEdisiRe visi. Andi.Yogyakarta

Al-Bahra Bin Ladjamudin. 2013. AnalisisdanDesainSistemInformasi. GrahaIlmu. Yogyakarta

Fatansyah. 2012. Strategi Perancangan dan Pengelolaan Basis Data.Andi. Yogyakarta

Hanif Al Fatta. 2007. StrategiPerancangandanPengelolaa $n$ Basis Data. Andi. Yogyakarta

Jogiyanto. 2009. Sistem Teknologi Informasi. Andi. Yogyakarta

Rusdiana. 2014. Sistem Informasi Manajemen. Bandung

Tata Sutabri. 2012. AnalisisSistemInformasi. Andi. Yogyakarta 